\title{
Environmental Pollution Cost Analyses of a Compression Ignition Diesel Engine Fuelled With Tire Pyrolytic Oil-Diesel Blends
}

\author{
Mustafa Karagoz ${ }^{1}$, Cuneyt Uysal ${ }^{1 *}$ \\ 0000-0002-2595-9002, 0000-0002-7986-1684 \\ ${ }^{1}$ Automotive Technologies Program, TOBB Vocational School of Technical Sciences, Karabuk University, 78050, Karabuk, Turkey.
}

\begin{abstract}
This paper represents the environmental pollution cost analysis of a single-cylinder, four-stroke, naturally aspirated, compression ignition diesel engine fuelled with tire pyrolytic oil (TPO)-diesel blends. TPO-diesel blends were prepared as 10 vol. $\%$ TPO + 90 vol.\% diesel (TPO10D90), 30 vol.\% TPO + 70 vol. $\%$ diesel (TPO30D70) and 50 vol.\% TPO + 50 vol.\% diesel (TPO50D50) blends. The experiments were conducted on test engine loads of $3 \mathrm{Nm}, 6 \mathrm{Nm}, 9 \mathrm{Nm}$ and $12 \mathrm{~m}$ and on constant crankshaft speed of $2000 \mathrm{rpm}$. It was found that TPO10D90 had better performance compared to neat diesel and other blends considered in this study in terms of environmental pollution cost analysis. As a result, at engine load of $3 \mathrm{Nm}$, the specific environmental pollution costs of neat diesel and TPO10D90 were obtained to be $0.05361 \$ / \mathrm{kWh}$ and $0.04724 \$ / \mathrm{kWh}$, respectively. It can be concluded that TPO-diesel blends having low TPO content can be used as alternative fuel for neat diesel in diesel engines in terms of environmental pollution cost analysis.
\end{abstract}

Keywords: Diesel engine; Environmental pollution cost analysis; Tire pyrolytic oil; Waste management.

\author{
* Corresponding author \\ Cuneyt Uysal \\ cuneytuysal@karabuk.edu.tr
}

Address: Automotive Technologies Program, TOBB Vocational School of Technical Sciences, Karabuk University, 78050, Karabuk, Turkey.

Tel:+903704189428

Fax: +903704189345

Research Article

Manuscript

Received $\quad 10.09 .2020$

Revised $\quad 17.10 .2020$

Accepted 26.10.2020

Doi: 10.30939/ijastech..793392

\section{Introduction}

Increasing energy consumption demand and wastes from consumption due to growing population and rapid industrialization causes to depletion of fossil fuel reserves and environmental degradation. This situation has led researchers to focus on alternative energy sources and waste recycling. In the last decade, the pyrolysis of waste tires has been receiving considerable attention by researchers to produce alternative fuels for internal combustion engines and to prevent the formation of waste tire dumps and their environmental effects.

In 1999, nearly 57 million vehicles (cars and commercial vehicles) were produced around the world. This production amount reached up to about 96 million in 2018 [1]. Rapidly increase in production of passenger cars, trucks and other vehicles has been causing to increasing tire production demand and hence increasing waste tires amount. Each year about 1.5 billion tires are produced around the world. This value corresponds to an estimated 17 million tons of used tires [2].

Waste tires can be recycled with several applications such as usage on basketball courts, flooring materials, patio decks, dock bumpers, railroad crossing blocks, livestock mats, sidewalks, steel manufacturing, cement and asphalt manufacturing, fuel production etc. Among these applications, fuel production may be more favorable due to that it allows both waste tire recycling and energy saving. The fuel production process is realized with pyrolysis method. The pyrolysis oil from waste tires has become a potential replacement for petroleum diesel.

Jantaraksa et al. [3] produced tire pyrolysis oil (TPO) and used hydrodesulfurization catalyzation to reduce the amount of sulfur compounds in fuel. The heating value of hydrodesulfurized TPO (44 MJ/kg) was the almost same with conventional diesel $(45 \mathrm{MJ} / \mathrm{kg})$ and gasoline $(47 \mathrm{MJ} / \mathrm{kg})$ fuels. Idris et al. [4] produced TPO like neat diesel except lower flash point and calorific value $(42.39 \mathrm{MJ} / \mathrm{kg})$ at the optimal pyrolysis temperature of $500{ }^{\circ} \mathrm{C}$ with the microwave-induced pyrolysis technique. Luo and Feng [5] produced TPO with using sensible heat of blast furnace slag in the pyrolysis of the waste tire. The obtained fuel had a lower density, viscosity, hydrogen $(\mathrm{H})$ and oxygen $(\mathrm{O})$ content and higher calorific value, carbon $(\mathrm{C})$ content and $\mathrm{C} / \mathrm{H}$ ratio compared to TPO produced from solely tire powder. 
Ilkilic and Aydin [6] tested the performance of a diesel engine fuelled with TPO-diesel blends in terms of engine power, engine torque, brake specific fuel consumption, exhaust temperature and emission parameters. They reported that TPO-diesel blends can efficiently be used in diesel engines without any modifications. However, considerably high $\mathrm{CO}, \mathrm{HC}, \mathrm{SO}_{2}$ and smoke emissions were observed for the blends having TPO ratios higher than $50 \%$. Bodisco et al. [7] reported that the $\mathrm{NO}_{\mathrm{x}}$ emissions when a diesel engine is fuelled with TPO-diesel blends are not significantly different than that of neat diesel. Frigo et al. [8] evaluated the performance of single-cylinder diesel engine fuelled with 20 vol. $\%$ TPO+ 80 vol. $\%$ diesel and 40 vol. $\%$ TPO+ 60 vol. $\%$ diesel blends. It was found that the blend having $20 \mathrm{vol} . \%$ TPO did not perform significantly different performance in terms of engine power, engine torque, specific fuel consumption and exhaust emissions compared to neat diesel. However, the engine combustion characteristics deteriorated when the engine was fuelled with the blend having 40 vol.\% TPO. Murugan et al. [9] investigated the performance of a diesel engine fuelled with distilled TPO-diesel blends without any engine modification. Lower $\mathrm{NO}_{\mathrm{x}}$ and higher $\mathrm{HC}$ and $\mathrm{CO}$ exhaust emissions compared to diesel fuel were observed when TPO diesel blends are used. Karagoz et al. [10] reported that brake specific fuel combustion increased and break thermal efficiency decreased with increasing TPO content of TPO-diesel blends. TPO-diesel blends had longer ignition delay compared to neat diesel. When TPO content was increased, $\mathrm{NO}_{\mathrm{x}}$ emissions slightly increased and $\mathrm{HC}$ gradually decreased. Martinez et al. [11] found that TPO-diesel blends had the almost same brake specific fuel consumption and brake thermal efficiency at high engine loads. However, at low engine loads, TPO addition to neat diesel deteriorate these parameters. Hurdogan et al. [12] reported that TPO-diesel blends showed similar performance with neat diesel in terms of torque and power output of test engine. Dogan et al. [13] tested TPO-diesel blends for five different TPO content $(10 \%, 30 \%, 50 \%, 70 \%$ and $90 \%$ in volume basis) in a diesel engine. In their study, it was found that TPO does not have an important effect on the engine output torque, engine power, break specific fuel consumption and break thermal efficiency of test engine. Karagoz et al. [14] investigated the performance of a diesel engine fuelled with TPO-diesel blends in terms of energy, exergy, economics and sustainability. At engine load of $12 \mathrm{Nm}$, TPO-diesel blend including $10 \%$ TPO had exergy efficiency of $26.36 \%$ and sustainability index of 1.358 , while exergy efficiency and sustainability index of test engine were determined to be $25.19 \%$ and 1.337 for neat diesel, respectively.

Koc and Abdullah [15] investigated the engine power, engine torque, brake specific fuel consumption and exhaust emissions of a four-cylinder, light-duty compression ignition (CI) engine fuelled with the binary and ternary blends of TPO, biodiesel and certified \#2 diesel fuels. The blend with $10 \%$ TPO $+10 \%$ biodiesel $+80 \%$ diesel provided the highest engine power and engine torque and it significantly reduced the brake specific fuel consumption. In addition, this blend provided lower $\mathrm{NO}_{\mathrm{x}}$ and $\mathrm{CO}$ emissions than the $10 \%$ biodiesel+ $90 \%$ diesel binary blend. Karagoz [16] found that butanol addition to TPO-diesel blend decreased the CO, HC and $\mathrm{NO}_{\mathrm{x}}$ emissions of blend. In addition, butanol addition to TPO-diesel blend led to decrease of brake specific fuel consumption and increase of brake thermal efficiency. Tudu et al. [17] investigated the effect of diethyl ether addition to 40 vol. $\%$ TPO+ 60 vol.\% diesel blend. The ignition delay was reduced with increasing diethyl ether content. $4 \%$ diethyl ether addition to the blend reduced about $6 \%$ the brake specific fuel consumption and about $25 \%$ the $\mathrm{NO}_{\mathrm{x}}$ emission compared to neat diesel. Mikulski et al. [18] tested ternary mixtures of rapeseed oil, TPO and diesel blends in a common-rail compression ignition diesel engine. They reported that blends containing a large fraction of rapeseed oil (up to $55 \%$ by volume) could be effectively combusted when TPO was used as additive.

Literature survey revealed that TPO-diesel blends did not perform significantly different performance compared to neat diesel in terms of engine power, engine torque, specific fuel consumption and they can be used in diesel engines without any engine modification. However, exhaust emissions are more susceptible compared to other parameters for changes of TPO ratio in blends. Yildiz et al. [19] presented environmental pollution cost analysis with combining economic and environmental parameters. They compared biodiesel and diesel fuel usage for diesel engines with considering this analysis and reported that the diesel fuel usage for diesel engine is slightly better option than biodiesel fuel in terms of environmental pollution cost analysis for better environmental management.

In this study, neat diesel, 10 vol. $\%$ TPO + 90 vol. $\%$ diesel (TPO10D90), 30 vol.\% TPO + 70 vol.\% diesel (TPO30D70) and 50 vol.\% TPO + 50 vol. $\%$ diesel (TPO50D50) blends were tested on a single-cylinder, four-stroke, naturally aspirated, CI diesel engine. The study was performed for different engine loads of $3 \mathrm{Nm}, 6 \mathrm{Nm}, 9 \mathrm{Nm}$ and $12 \mathrm{Nm}$ and for constant crankshaft speed of $2000 \mathrm{rpm}$. TPO-diesel blends utilization in the diesel engine were firstly compared with neat diesel in terms of environmental pollution cost analysis in this study. 


\section{System Description}

The system diagram is shown in Figure 1.

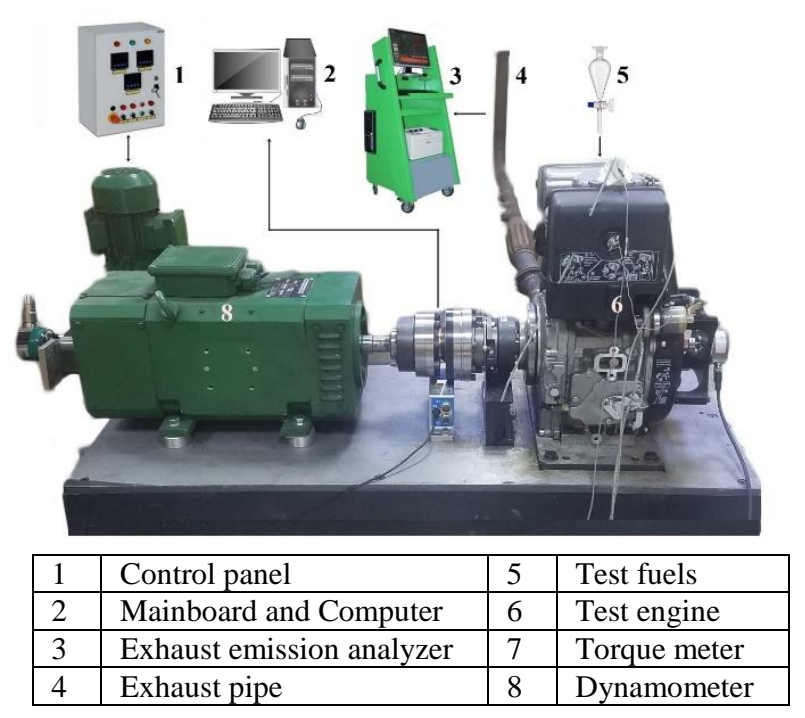

Fig. 1. Test engine and experimental setup

As can be seen from Figure 1, the test system was including test engine, generator, exhaust gas analyzer and torque measurement apparatus. The test engine was a single-cylinder, four-stroke, naturally aspirated, compression ignition (CI) diesel engine. The cylinder diameter and cylinder stroke for the test engine was $82 \mathrm{~mm}$ and $66 \mathrm{~mm}$, respectively. In addition, the test engine has a compression ratio of 20.3/1 and the opening pressure for injector nozzle is 207 bar. Kemsan trademark generator is connected to the test engine with coupling. The generator can regulate the test engine load and it is necessary to provide different test engine loads. The experiments were performed on the different engine loads of 3 $\mathrm{Nm}, 6 \mathrm{Nm}, 9 \mathrm{Nm}$ and $12 \mathrm{Nm}$ and on the constant crankshaft speed of $2000 \mathrm{rpm}$. The effective power values correspond to these engine loads were $0.6283 \mathrm{~kW}, 1.2567 \mathrm{~kW}, 1.8850$ $\mathrm{kW}$ and $2.5134 \mathrm{~kW}$, respectively. The torque values were measured with a torque gauge, which is Kistler Rotor type 4550A magnetic torque measuring device ( $\left.\begin{array}{llll}0 & 100 & 0 & 5000\end{array}\right)$. The $\mathrm{CO}_{2}$ emissions of test engine were measured with the $\mathrm{K}$ Test exhaust emission analyzer (C with $015 \%, \mathrm{CO}_{2}$ with 0 20\%, $\mathrm{HC}$ with $02000 \mathrm{ppm}, \mathrm{NO}_{\mathrm{x}}$ with $05000 \mathrm{ppm}$ ). This device can also measure $\mathrm{NO}_{\mathrm{x}}, \mathrm{CO}$ and $\mathrm{HC}$ emissions precisely.

\section{Preparation of Test Fuels}

The vacuum pyrolysis technique was used to produce the TPO from waste tires. Several processes were followed to upgrade the properties of TPO. Firstly, $8 \mathrm{~g}$ hydro-sulfuric acid $\left(\mathrm{H}_{2} \mathrm{SO}_{4}\right)$ per $100 \mathrm{~g}$ TPO was added and the mixture was preheated up to $50^{\circ} \mathrm{C}$. The mixture was stirred with a mechanical stirrer for $4 \mathrm{~h}$ and then left to rest for $50 \mathrm{~h}$. After this process, the mixture was filtrated and then $5 \mathrm{~g}$ calcium oxide and $10 \mathrm{~g}$ activated bentonite per $95 \mathrm{~g}$ mixture was added. The new mixture prepared was heated up to $70^{\circ} \mathrm{C}$ and stirred with mechanical stirrer for $4 \mathrm{~h}$. The mixture was left to rest for $24 \mathrm{~h}$. To decontaminate from sludge, the mixture was filtrated. The vacuum distillation process was used to distill the mixture. After this process, the oxidative desulfurization process was applied to reduce the sulfur content of mixture. For this process, $10 \mathrm{~g}$ formic acid and $20 \mathrm{~g}$ hydrogen peroxide per $95 \mathrm{~g}$ mixture was added. The mixture was stirred for $2 \mathrm{~h}$ at a fixed temperature of $60^{\circ} \mathrm{C}$ and then left to rest for $24 \mathrm{~h}$. After this process, the mixture was filtrated with fabric filter and diesel fuel filter, respectively. The mixture was washed with distilled water. In washing process, $200 \mathrm{~mL}$ distilled water per $1000 \mathrm{~mL}$ mixture was used. Finally, the mixture was heated up to $110^{\circ} \mathrm{C}$ for $30 \mathrm{~min}$ to dehumidify. By this way, TPO used in this study was obtained.

Diesel fuel was procured from a commercial company. Table 1 shows the properties of diesel fuel and TPO used in this study.

Table 1. Properties of diesel fuel and TPO used in this study

\begin{tabular}{c|c|c} 
Property & Diesel fuel & TPO \\
\hline Density $\left(\mathrm{kg} / \mathrm{m}^{3} ;\right.$; $\left.15{ }^{\circ} \mathrm{C}\right)$ & 835 & 899 \\
\hline Cetane number & 54.92 & $<40$ \\
\hline Viscosity $\left(\mathrm{cSt}\right.$; @ $\left.40^{\circ} \mathrm{C}\right)$ & 2.929 & 2.153 \\
\hline Lower heating value $(\mathrm{MJ} / \mathrm{kg})$ & 45.94 & 40.88 \\
\hline Flash point $\left({ }^{\circ} \mathrm{C}\right)$ & 60 & 60.3 \\
\hline Carbon content $($ wt. \%) & 86.74 & 86.17 \\
\hline Hydrogen content $(\mathrm{wt} . \%)$ & 13.26 & 10.31 \\
\hline Nitrogen content $(\mathrm{mg} / \mathrm{kg})$ & 44 & 820 \\
\hline Oxygen content $(\mathrm{wt.} \%)$ & 0 & 0
\end{tabular}

Diesel fuel and TPO were blended for different volumetric ratios. TPO10D90, TPO30D70 and TPO50D50 blends were used in the experiments.

\section{Methodology}

The environmental pollution cost analysis is based on costing of environmental impact of the $\mathrm{CO}_{2}$. This methodology combines the economic and environmental analyses. The emitted $\mathrm{CO}_{2}$ emission rates are converted to economical aspects with using cost of $\mathrm{CO}_{2}$. By this way, the environmental costs can be calculated. The aim of this method is to investigate the economic aspects of environmental aspects and the cost of environmental impact of $\mathrm{CO}_{2}$ [19]. The cost of $\mathrm{CO}_{2}$ was determined to be $C_{\mathrm{CO} 2}=0.0327 \$ / \mathrm{kg}$ [20].

The specific environmental pollution cost $(S E P)$ can be given as follow [19]:

$\mathrm{SEP}=\mathrm{C}_{\mathrm{CO}_{2}} e_{\mathrm{CO}_{2}}$ 
where $C_{\mathrm{CO}_{2}}$ is the cost of $\mathrm{CO}_{2}$ emission and $e_{\mathrm{CO} 2}$ is the $\mathrm{CO}_{2}$ emission emitted from the test engine.

The cost of the $\mathrm{CO}_{2}$ emission emitted from the test engine during the lifetime of test engine is defined as the total environmental pollution cost (TEP) and it can be calculated with following expression [19]:

$T E P=C_{\mathrm{CO}_{2}}\left(e_{\mathrm{CO}_{2}} P N t\right)$

where $P$ is the effective power, $N$ is the operating hours in a year and $t$ is the total lifetime of test engine. The operating hours in a year and total lifetime of test engine are determined to be $8000 \mathrm{~h} /$ year and 20 year, respectively.

The life cycle based total environmental pollution cost $\left(T E P_{L C}\right)$ considers the cost of $\mathrm{CO}_{2}$ emission emitted from the test engine and the pollution costs caused by the production of the test engine and fuel. $T E P_{L C}$ can be expressed as follows [19]:

$$
T E P_{L C}=C_{\mathrm{CO}_{2}}\left[\left(e_{\mathrm{CO}_{2}} P N t\right)+\left(m_{I C E} e_{I C E}\right)+\left(\dot{Q}_{F} e_{F} N t\right)\right]
$$

where $m_{I C E}$ is the mass of test engine, $e_{I C E}$ is the emission rate of test engine material, $\dot{Q}_{F}$ is the heat energy of fuel and $e_{F}$ is the emission caused by the fuel production process. The mass of test engine was measured to be $m_{I C E}=33$ $\mathrm{kg}$. The emission rate of test engine material was assumed to be $e_{I C E}=3.012 \mathrm{kgCO}_{2} / \mathrm{kg}[19,20]$. The emission caused by the fuel production process was $0.083 \mathrm{kgCO}_{2} / \mathrm{MJ}$ for neat diesel and $0.082 \mathrm{kgCO}_{2} / \mathrm{MJ}$ for TPO $[19,20]$. The emission caused by the fuel production process for TPO-diesel blends was calculated with considering mass fractions of TPO and neat diesel in TPO-diesel blend as follows:

$e_{F}=\frac{\dot{m}_{D} e_{F, D}+\dot{m}_{T P O} e_{F, T P O}}{\dot{m}_{D}+\dot{m}_{T P O}}$

The life cycle based specific environmental pollution cost $\left(S E P_{L C}\right)$ can be expressed as follows [19]:

$$
S E P_{L C}=\frac{T E P_{L C}}{(P N t)}
$$

The total $\mathrm{CO}_{2}$ emission parameter $(£)$ can be given as follows [20]:

$$
£=\frac{\dot{m}_{\mathrm{CO}_{2}}}{\dot{W}_{\text {net }}}
$$

where $\dot{m}_{\mathrm{CO} 2}$ is the mass flow rate of $\mathrm{CO}_{2}$ emission emitted by the test engine and $\dot{W}_{n e t}$ is the network output rate of the test engine.

The payback period of test engine $(P P)$ can be expressed as follows [21]:

$P P=\frac{4.3(P E C+O M)}{N\left(\dot{W}_{n e t} c_{e l}+\dot{Q}_{F} c_{F}\right)}$

where $P E C$ is the purchased equipment cost, $O M$ operation and maintenance cost, $c_{e l}$ is the electricity price and $c_{F}$ is the fuel price.

The environmental payback period ( $E P P$ ) can be given as follows [20]:

$E P P=\frac{T E P}{N \dot{W}_{n e t} c_{e l}}$

The life cycle based environmental payback period $\left(E P P_{L C}\right)$ can be expressed as follows [20]:

$E P P_{L C}=\frac{T E P_{L C}}{N \dot{W}_{n e t} c_{e l}}$

The purchased equipment cost of test engine was $P E C=$ $60000 \$$. The unit cost of electricity and neat diesel was $c_{e l}=$ $0.1212 \$ / \mathrm{kWh}[22]$ and $c_{F}=2.932 \times 10^{-5} \$ / \mathrm{kJ}$ [22]. The unit cost of TPO-diesel blends was $c_{F}=2.792 \times 10^{-5} \$ / \mathrm{kJ}$ for TPO10D90, $c_{F}=2.507 \times 10^{-5} \$ / \mathrm{kJ}$ for TPO30D70 and $c_{F}=$ $2.218 \times 10^{-5} \$ / \mathrm{kJ}$ for TPO50D50. The operation and maintenance cost of test engine can be considered as $1.092 \%$ of purchased equipment cost [23].

\section{Results and Discussions}

In this study, the environmental pollution cost analysis of a single-cylinder, four-stroke, naturally aspirated, CI diesel engine fuel with neat diesel, TPO10D90, TPO30D70, TPO50D50 was performed on for the engine loads of $3 \mathrm{Nm}$, $6 \mathrm{Nm}, 9 \mathrm{Nm}$ and $12 \mathrm{Nm}$ at constant crankshaft speed of 2000 rpm.

The measured $\mathrm{CO}_{2}$ emissions of the test engine for TPOdiesel blends considered in this study at different test engine loads were given in Figure 2. 


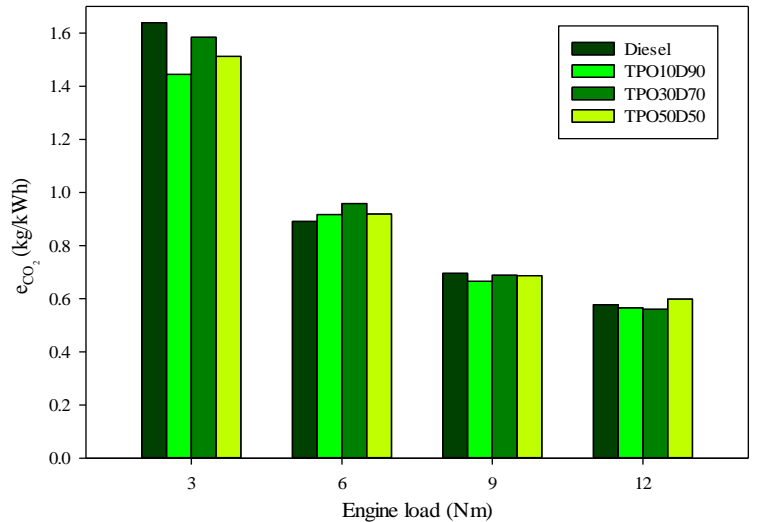

Fig. 2. $\mathrm{CO}_{2}$ emissions emitted by the test engine

The $\mathrm{CO}_{2}$ emissions emitted by the test engine decreased with increase in test engine load. At test engine load of $3 \mathrm{Nm}$ and $9 \mathrm{Nm}$, the highest $\mathrm{CO} 2$ emissions were observed for neat diesel. It was followed by TPO30D70, TPO50D50 and TPO10D90, respectively. The highest $\mathrm{CO} 2$ emission at test engine load of $6 \mathrm{Nm}$ was observed for TPO30D70 and it was followed by TPO50D50, TPO10D90 and neat diesel, respectively. At test engine load of $12 \mathrm{Nm}$, the highest $\mathrm{CO} 2$ emission was observed for TPO50D50 and it was followed by neat diesel, TPO10D90 and TPO30D70, respectively. The reduction in $\mathrm{CO} 2$ emission with TPO addition is due to decreasing oxygen content of air-fuel mixture. TPO addition to diesel fuel reduced the air-fuel ratio. However, increasing TPO content increased the air-fuel ratio.

The SEP, TEP, SEP $P_{L C}$ and $T E P_{L C}$ values of testengine for TPO-diesel blends were represented in Figures 3-6.

The lowest values of SEP and TEP at test engine load of $3 \mathrm{Nm}$ and $9 \mathrm{Nm}$ were obtained for TPO10D90, while the highest ones were obtained for neat diesel. At test engine load of $6 \mathrm{Nm}$, the lowest and the highest values of SEP and TEP were observed for neat diesel and TPO30D70, respectively. At test engine load of $12 \mathrm{Nm}$, the lowest and the highest values of SEP and TEP were observed for TPO30D70 and TPO50D50, respectively. For all cases considered in this study, the highest $S E P$ value was obtained to be $0.0536 \$ / \mathrm{kWh}$ for neat diesel at $3 \mathrm{Nm}$, while the lowest one was obtained to be $0.0183 \$ / \mathrm{kWh}$ for TPO30D70 at 12 $\mathrm{Nm}$. In addition to this, the highest $T E P$ value was found to be 7869.87 \& for TPO50D50 at $12 \mathrm{Nm}$, while the lowest one was obtained to be $4749.29 \$$ for TPO10D90 at $3 \mathrm{Nm}$ when all cases were considered. The $S E P$ values of TPO10D90 were calculated to be $0.04724 \$ / \mathrm{kWh}$ at $3 \mathrm{Nm}$, $0.02999 \$ / \mathrm{kWh}$ at $6 \mathrm{Nm}, 0.02175 \$ / \mathrm{kWh}$ at $9 \mathrm{Nm}$ and $0.01850 \$ / \mathrm{kWh}$ at $12 \mathrm{Nm}$. Similarly, The TEP values of TPO10D90 were determined to be $4749.29 \$$ at $3 \mathrm{Nm}$, $6029.99 \$$ at $6 \mathrm{Nm}, 6559.69 \$$ at $9 \mathrm{Nm}$ and $7437.56 \$$ at 12 $\mathrm{Nm}$. The TEP values of neat diesel were obtained to be $5389.77 \$$ at $3 \mathrm{Nm}, 5861.49 \$$ at $6 \mathrm{Nm}, 6858.62 \$$ at $9 \mathrm{Nm}$ and $7597.05 \$$ at $12 \mathrm{Nm}$.

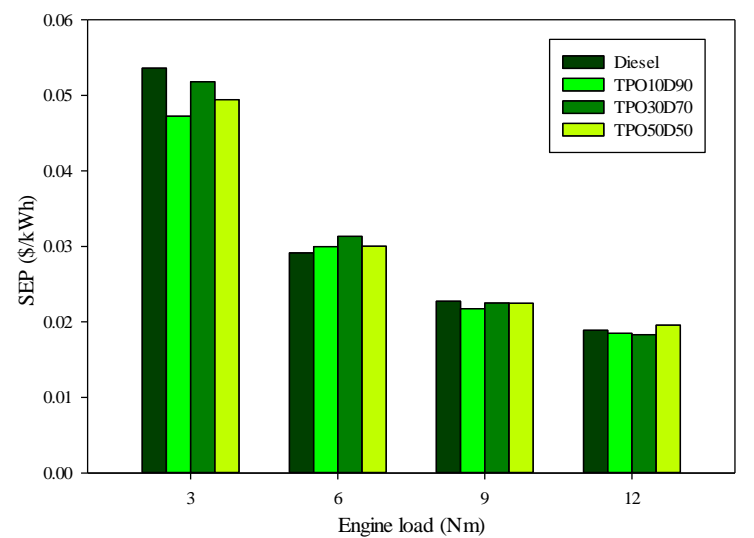

Fig. 3. Specific environmental pollution cost

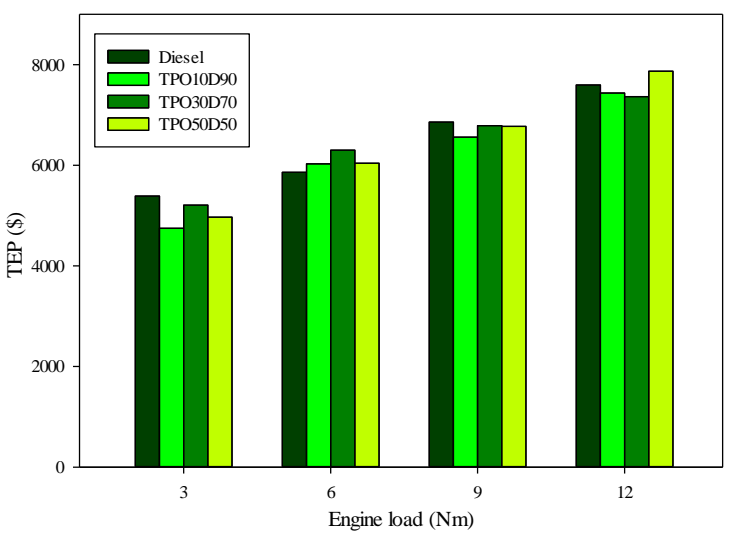

Fig. 4. Specific environmental pollution cost

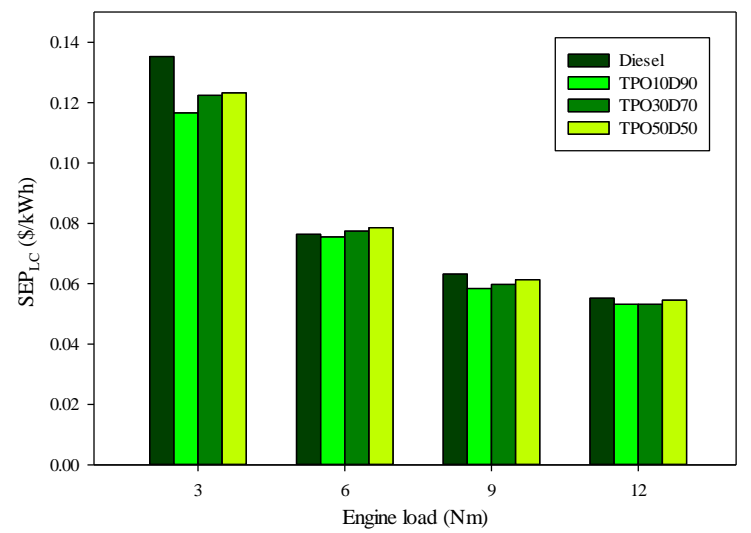

Fig. 5. Life cycle based specific environmental pollution cost 


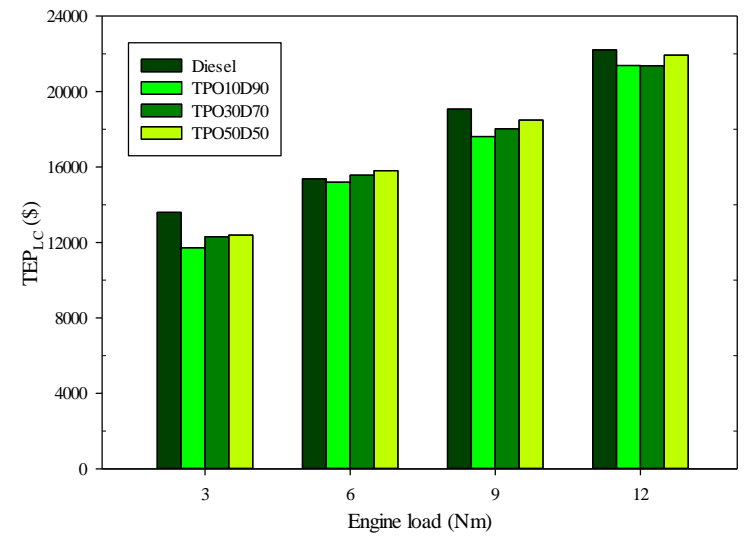

Fig. 6. Life cycle based total environmental pollution cost

The $S E P_{L C}$ and $T E P_{L C}$ values were ordered as neat diesel $>$ TPO50D50 > TPO30D70 > TPO10D90 at $3 \mathrm{Nm}$ and $9 \mathrm{Nm}, \mathrm{TPO} 50 \mathrm{D} 50>\mathrm{TPO} 30 \mathrm{D} 70>$ neat diesel $>$ TPO10D90 at $6 \mathrm{Nm}$ and neat diesel > TPO50D50 > TPO10D90 > TPO30D70 at $12 \mathrm{Nm}$. When all cases in the study were considered, the highest $S E P_{L C}$ value was obtained to be 0.1353 $\$ / \mathrm{kWh}$ for neat diesel at $3 \mathrm{Nm}$, while the lowest one was found to be $0.0531 \$ / \mathrm{kWh}$ for TPO30D70 at $12 \mathrm{Nm}$. Similarly, the highest and lowest $T E P_{L C}$ values were obtained to be $22210.91 \$$ for neat diesel at $12 \mathrm{Nm}$ and $11723.11 \$$ for TPO10D90 at $3 \mathrm{Nm}$, respectively. It was also observed that the obtained $S E P$ and TEP values were lower compared to the $S E P_{L C}$ and $T E P_{L C}$ values, respectively. The $S E P_{L C}$ values of neat diesel were determined to be 0.1353 $\$ / \mathrm{kWh}$ at $3 \mathrm{Nm}, 0.0764 \$ / \mathrm{kWh}$ at $6 \mathrm{Nm}, 0.0632 \$ / \mathrm{kWh}$ at 9 $\mathrm{Nm}$ and $0.0552 \$ / \mathrm{kWh}$ at $12 \mathrm{Nm}$. These values were calculated to be $0.1166 \$ / \mathrm{kWh}$ at $3 \mathrm{Nm}, 0.0756 \$ / \mathrm{kWh}$ at $6 \mathrm{Nm}$, $0.0584 \$ / \mathrm{kWh}$ at $9 \mathrm{Nm}$ and $0.0532 \$ / \mathrm{kWh}$ at $12 \mathrm{Nm}$ for TPO10D90. The $T E P_{L C}$ values of TPO10D90 were obtained to be $11723.11 \$$ at $3 \mathrm{Nm}, 15194.56 \$$ at $6 \mathrm{Nm}$, $17616.27 \$$ at $9 \mathrm{Nm}$ and $21381.95 \$$ at $12 \mathrm{Nm}$.

The $£, P P, E P P$ and $E P P_{L C}$ values of test engine for TPO-diesel blends were given in Figures 7-10.

Neat diesel had the highest $£$ value at test engine load of $3 \mathrm{Nm}$ and $6 \mathrm{Nm}$, while the lowest one was obtained for TPO10D90 at the same test engine loads. However, at $6 \mathrm{Nm}$, the blends were ordered as TPO30D70 > TPO50D50 > TPO10D90 > neat diesel for their $£$ values. This order changed as TPO50D50 > neat diesel > TPO10D90> TPO30D70 at test engine load of $12 \mathrm{Nm}$. The highest and lowest $£$ values for all cases considered in this study were obtained to be $4.5541 \times 10-4 \mathrm{~kg} / \mathrm{kJ}$ for neat diesel at $3 \mathrm{Nm}$ and $1.5560 \times 10-4 \mathrm{~kg} / \mathrm{kJ}$ for TPO30D70 at $12 \mathrm{Nm}$, respectively.

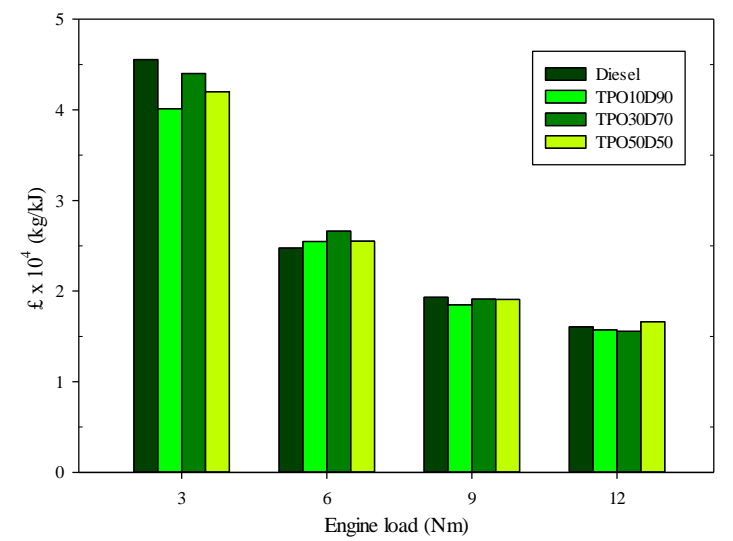

Fig. 7. Total $\mathrm{CO}_{2}$ emission parameter

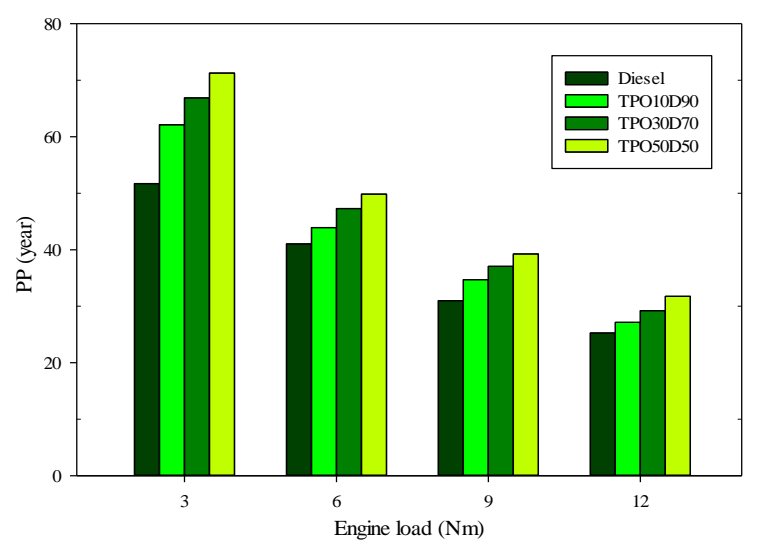

Fig. 8. Payback period

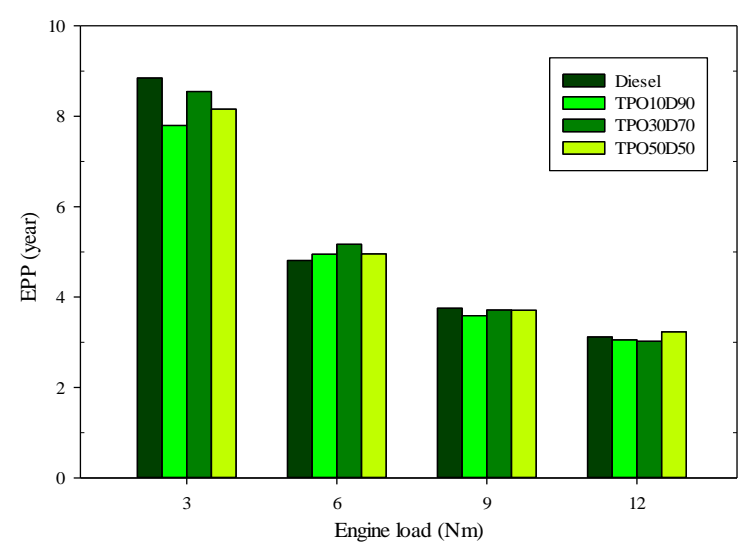

Fig. 9. Environmental payback period 


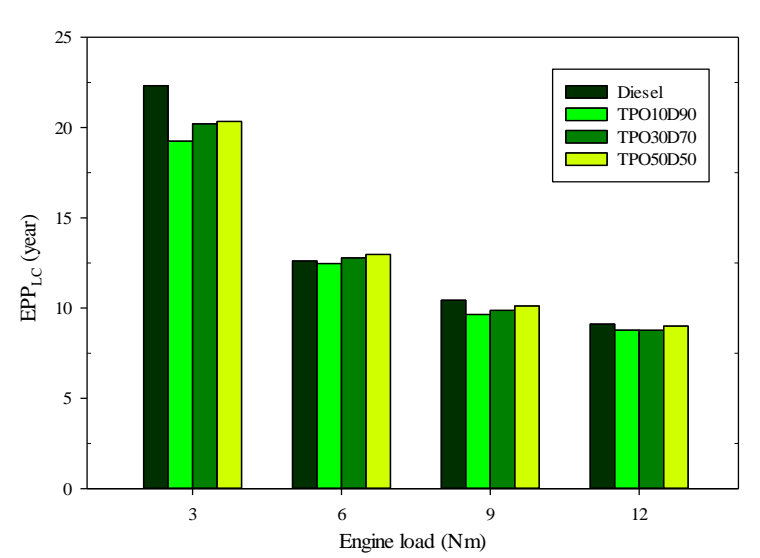

Fig. 10. Life cycle based environmental payback period

The $P P$ values decreased with increase in test engine load for all fuels considered in this study. According to their $P P$ values, the fuels were ordered as TPO50D50 > TPO30D70 > TPO10D90 > neat diesel at all test engine loads considered in this study. When this alignment was considered, it may be said that the $P P$ value decreased with decrease in TPO ratio of TPO-diesel blends. The highest $P P$ value was obtained to be 71.2696 year for TPO50D50 at $3 \mathrm{Nm}$, while the lowest $P P$ value was found to be 25.2490 year for neat diesel at $12 \mathrm{Nm}$. Neat diesel had the $P P$ value of 51.7264 year at $3 \mathrm{Nm}$.

TPO10D90 had the lowest EPP values at $3 \mathrm{Nm}, 9 \mathrm{Nm}$ and $12 \mathrm{Nm}$. At $6 \mathrm{Nm}$, neat diesel had the lowest EPP value. The highest EPP values were observed for neat diesel at $3 \mathrm{Nm}$ and $9 \mathrm{Nm}$, TPO30D70 at $6 \mathrm{Nm}$ and TPO50D50 at $12 \mathrm{Nm}$. For all cases considered in this study, the highest $E P P$ value was found to be 8.8471 year for neat diesel at 3 $\mathrm{Nm}$, while the lowest EPP value was obtained to be 3.0227 year for TPO30D70 at $12 \mathrm{Nm}$.

According to the $E P P_{L C}$ values, the fuels were ordered as neat diesel $>$ TPO50D50 > TPO30D70 > TPO10D90 at test engine loads of $3 \mathrm{Nm}$ and $9 \mathrm{Nm}$. At $6 \mathrm{Nm}$, this alignment was as TPO50D50 > TPO30D70 > neat diesel > TPO10D90. However, at $12 \mathrm{Nm}$, the fuels were ordered as neat diesel > TPO50D50 > TPO10D90 > TPO30D70 in regard to their $E P P_{L C}$ values. The highest and lowest $E P P_{L C}$ values for all cases considered in this study were obtained to be 22.3223 year for neat diesel at $3 \mathrm{Nm}$ and 8.7687 year for TPO30D70 at $12 \mathrm{Nm}$, respectively.

When the results were considered, low TPO content of TPO-diesel blends can have an advantage compared to neat diesel and TPO-diesel blends having high TPO content in terms of environmental pollution cost analysis except $P P$ parameter. Relatively lower values were obtained for TPO30D70 and especially for TPO10D90. This means that TPO10D90 showed better performance compared to neat diesel in terms of environmental pollution cost analysis.

\section{Conclusions}

Environmental pollution cost analysis was performed on single-cylinder, four-stroke, naturally aspirated, CI diesel engine fuelled with neat diesel, TPO10D90, TPO30D70 and TPO50D50 blends. The experiments were conducted on different test engine loads of $3 \mathrm{Nm}, 6 \mathrm{Nm}, 9 \mathrm{Nm}$ and $12 \mathrm{Nm}$ and on constant crankshaft speed of $2000 \mathrm{rpm}$. Some conclusions can be ordered as follows:

- At engine load of $3 \mathrm{Nm}, \mathrm{CO}_{2}$ emission emitted by test engine was determined to be $1.6395 \mathrm{~kg} / \mathrm{kWh}$ for neat diesel and $1.4447 \mathrm{~kg} / \mathrm{kWh}$ for TPO10D90. This value was determined to be $0.5777 \mathrm{~kg} / \mathrm{kWh}$ for neat diesel and 0.5656 $\mathrm{kg} / \mathrm{kWh}$ for TPO10D90 at $12 \mathrm{Nm}$.

- The specific environmental pollution cost and life cycle based specific environmental pollution cost values of neat diesel were calculated to be 0.0536 $\$ / \mathrm{kWh}$ and $0.1353 \$ / \mathrm{kWh}$, respectively, at engine load of $3 \mathrm{Nm}$. These values were calculated to be $0.0472 \$ / \mathrm{kWh}$ and $0.1166 \$ / \mathrm{kWh}$ for TPO10D90.

- At engine load of $3 \mathrm{Nm}$, the total environmental pollution costs of neat diesel and TPO10D90 were obtained to be $5389.77 \$$ and 4749.29 \$, respectively. The life cycle based total environmental pollution cost value was determined to be 13598.98 \$ for neat diesel and 11723.11 \$ for TPO10D90.

- The environmental payback period and life cycle based environmental payback period values of neat diesel were obtained to be 8.8471 year and 22.3223 year, respectively, at engine load of 3 $\mathrm{Nm}$. These values were determined to be 7.7958 year and 19.2431 year, respectively.

In general framework, it may be said that TPO10D90 had better performance and increasing in TPO content of blends made worse the results. Similar trend of TPO-diesel blends for engine power output, combustion characteristics and exhaust emissions has been reported by References [6, 8, 12, 14]. Finally, it can be said that TPO-diesel blends having low TPO content can be used as alternative fuel for neat diesel in diesel engines in the perspective of environmental pollution cost analysis.

\section{Nomenclature}

$\begin{array}{ll}c_{e l} & : \text { electricity price }(\$ / \mathrm{kJ}) \\ c_{F} & : \text { fuel price }(\$ / \mathrm{kJ}) \\ C_{\mathrm{CO}_{2}} & : \text { cost of carbon dioxide }(\$ / \mathrm{kg}) \\ e_{\mathrm{CO}_{2}} & : \text { carbon dioxide emission emitted from test en- } \\ & \text { gine }(\mathrm{kg} / \mathrm{kWh}) \\ e_{F} & : \text { emission caused by fuel production process } \\ & \left(\mathrm{kgCO}_{2} / \mathrm{MJ}\right)\end{array}$




\begin{tabular}{|c|c|}
\hline$e_{I C E}$ & : emission rate of test engine $\left(\mathrm{kgCO}_{2} / \mathrm{kg}\right)$ \\
\hline$E P P$ & : environmental payback period (year) \\
\hline$E P P_{L C}$ & $\begin{array}{l}\text { : life cycle based environmental payback period } \\
\text { (year) }\end{array}$ \\
\hline$£$ & $\begin{array}{l}\text { : total carbon dioxide emission parameter } \\
(\mathrm{kg} / \mathrm{kJ})\end{array}$ \\
\hline$m_{I C E}$ & : mass of test engine $(\mathrm{kg})$ \\
\hline$\dot{m}_{\mathrm{CO}_{2}}$ & $\begin{array}{l}\text { mass flow rate of carbon dioxide emission } \\
\text { emitted by test engine }(\mathrm{kg} / \mathrm{s})\end{array}$ \\
\hline$\dot{m}_{D}$ & : mass flow rate of diesel $(\mathrm{kg} / \mathrm{s})$ \\
\hline$\dot{m}_{T P O}$ & : mass flow rate of tire pyrolytic oil (kg/s) \\
\hline$N$ & : operating hours in a year (h/year) \\
\hline$O M$ & : operation and maintenance cost $(\$)$ \\
\hline$P$ & : effective power $(\mathrm{kW})$ \\
\hline$P E C$ & : purchased equipment cost $(\$)$ \\
\hline$P P$ & : payback period (year) \\
\hline$\dot{Q}_{F}$ & : heat energy of fuel $(\mathrm{kJ} / \mathrm{h})$ \\
\hline$S E P$ & : specific environmental pollution cost $(\$ / \mathrm{kWh})$ \\
\hline$S E P_{L C}$ & $\begin{array}{l}\text { : life cycle based specific environmental pollu- } \\
\text { tion cost }(\$ / \mathrm{kWh})\end{array}$ \\
\hline$t$ & : total lifetime (year) \\
\hline$T E P$ & : total environmental pollution cost $(\$)$ \\
\hline$T E P_{L C}$ & $\begin{array}{l}\text { : life cycle based total environmental pollution } \\
\text { cost }(\$)\end{array}$ \\
\hline$\dot{W}_{n e t}$ & : net work output of test engine $(\mathrm{kW})$ \\
\hline
\end{tabular}

\section{References}

[1] IOMVM. (2020). International Organization of Motor Vehicle Manufacturers. www.oica.net. 16 January 2020.

[2] Czajczynska, D., Krzyzynska, R., Jouhara, H. and Spencer, N. (2017). Use of pyrolytic gas from waste tire as a fuel: A review. Energy, 134, 1121-1131.

[3] Jantaraksa, N., Prasassarakich, P., Reubroycharoen, P. and Hinchiranan, N. (2015). Cleaner alternative liquid fuels derived from the hydrodesulfurization of waste tire pyrolysis oil. Energy Conversion and Management, 95, 424-434.

[4] Idris, R., Chong, C.T. and Farid, N.A. (2019) Microwave-induced pyrolysis of waste truck tyres with carbonaceous susceptor for the production of diesel-like fuel. Journal of the Energy Institute, 92, 1831-1841.

[5] Luo, S. and Feng, Y. (2017). The production of fuel oil and combustible gas by catalytic pyrolysis of waste tire using waste heat of blast-furnace slag. Energy Conversion and Management, 136, 27-35.

[6] Ilkilic, C. and Aydin, H. (2011). Fuel production from waste vehicle tires by catalytic pyrolysis and its application in a diesel engine. Fuel Processing Technology, 92, 1129-1135.

[7] Bodisco, T.A., Rahman, S.M.A., Hossain, F.M. and Brown, R.J. (2019). On-road NOx emissions of a modern commercial light-duty diesel vehicle using a blend of tyre oil and diesel. Energy Reports, 5, 349-356.

[8] Frigo, S., Seggiani, M., Puccini, M. and Vitolo, S. (2014). Liquid fuel production from waste tyre pyrolysis and its utilisation in a Diesel engine. Fuel, 116, 399-408.

[9] Murugan, S., Ramaswamy, M.C. and Nagarajan, G. (2008). Performance, emission and combustion studies of a DI diesel engine using distilled tyre pyrolysis oil-diesel blends. Fuel Processing Technology, 89, 152-159.

[10] Karagoz, M., Agbulut, U. and Saridemir, S. (2020). Waste to energy: Production of waste tire pyrolysis oil and comprehensive analysis of its usability in diesel engines. Fuel, 275, 117844.

[11] Martinez, J.D., Rodriguez-Fernandez, J., Sanchez-Valdepenas, J., Murillo, R. and Garcia, T. (2014). Performance and emissions of an automotive diesel engine using a tire pyrolysis liquid blend. Fuel, 115, 490-499.

[12] Hurdogan, E., Ozalp, C., Kara, O. and Ozcanli M. (2017). Experimental investigation on performance and emission characteristics of waste tire pyrolysis oil-diesel blends in a diesel engine. International Journal of Hydrogen Energy, 42, 23373 -23378 .

[13] Dogan, O., Celik, M.B. and Ozdalyan, B. (2012). The effect of tire derived fuel/diesel fuel blends utilization on diesel engine performance and emissions. Fuel, 95, 340-346.

[14] Karagoz, M., Uysal, C., Agbulut, U. and Saridemir, S. (2020). Energy, exergy, economic and sustainability assessments of a compression ignition diesel engine fueled with tire pyrolytic oil diesel blends. Journal of Cleaner Production, 264, 121724.

[15] Koc, A.B. and Abdullah, M. (2014). Performance of a 4-cylinder diesel engine running on tire oil-biodiesel-diesel blend. Fuel Processing Technology, 118, 264-269.

[16] Karagoz, M. (2020). Investigation of performance and emission characteristics of an CI engine fuelled with diesel - waste tire oil - butanol blends. Fuel, 282, 118872.

[17] Tudu, K., Murugan, S. and Patel, S.K. (2016). Effect of diethyl ether in a DI diesel engine run on a tyre derived fueldiesel blend. Journal of the Energy Institute, 89, 525-535.

[18] Mikulski, M., Walacik, M.A., Duda, K. and Hunicz, J. (2020). Performance and emission characterization of a common-rail compression-ignition engine fuelled with ternary mixtures of rapeseed oil, pyrolytic oil and diesel. Renewable Energy, 148, 739-755.

[19] Yildiz, I., Acikkalp, E., Caliskan, H. and Mori, K. (2019). Environmental pollution cost analyses of biodiesel and diesel fuels for a diesel engine. Journal of Environmental Management, 243, 218-226.

[20] Kanbur, B.B., Xiang, L., Dubey, S., Choo, F.H. and Duan F. (2018). Life cycle-based enviroeconomic and thermal analyses of the inlet air-cooled microturbine systems with liquefied natural gas cold energy. Journal of Cleaner Production, 174, 1338-1350.

[21] Bejan, A., Tsatsaronis, G. and Moran, M. (1995). Thermal Design and Optimization. John Wiley and Sons.

[22] EPDK. (2019). Republic of Turkey Energy Market Regulatory Authority, www.epdk.org.tr. 25 September 2019.

[23] Tsatsaronis, G. and Pisa, J. (1994). Exergoeconomic evaluation and optimization of energy systems-application to the CGAM problem. Energy, 19, 287-321. 